\title{
APPLICATION OF GOLDSOLREACTION TO ENZYMOLOGICAL STUDIES
}

\author{
TADAATSU NLKADA \\ Department of Pharmacology, Faculty of Medicine, Osaka University, Osaka \\ Received for publication September 24, 1962
}

It is well known that Zsigmondy (1) developed the preparation method of goldsol and investigated its physical and physiological properties. Later Lange (2-4) applied goldsolreaction to the cercbrospinal fluid, and it was introduced as Lange's Goldsolreaction. But the reaction mechanism of colloidal gold test is still unknown and is open to further study. The albumin which is essential element in cerebrospinal fluid has protecting action for goldsol, while the globulin acts coagulative for goldsol. If globulin is increased pathologically and albumin to globulin ratio (A/G) is decreased, colloid protecting action of cerebrospinal fluid may grow weak and the color of the goldsol suspension with cerebrospinal fluid changes in various degrees by increasing colloid lability. Since Maclagan et al. (5) examined extensively goldsolreaction with cercbrospinal fluid and blood after his research for conservation of goldsol, goldsolreaction has become to be utilized generally for clinical examination.

Nishino (6) who applied the goldsolreaction to antigen-antibody reaction found that the color of the medium altered when the antigen was added to the system in which goldsol was protected by antiserum against sodium chloride. By the addition of antizen the protecting action of antibody for goldsol was weakend and goldsol was coagulated.

In the present paper, the author represents some results on the goldsolreaction applying to the enzymological studies.

\section{MATERIALS AND METHODS}

Goldsol: Goldsol RV* prepared by Formalin-reduction method by Nishino was more stable and sensitive than the preparations of goldsol formerly reported. Goldsol RV was neutralized and coagulated with a contact of cation. Therefore, according to the reciprocity of the protectors to cations goldsol medium was changed in color in following order: pink, purple pink, purple, purple blue, light blue and colorless.

Acelylcholinesterase: Acetylcholinesterasc (ACh-ase) was prepared from rabbit erythrocytes with the method of Mounter and Whittaker $(7,8)$.

Lactic dehydrogenase: Lactic dehydrogenase was purified from bovine heart muscle

* Colloidchemical Corporation, Ehime, Japan. 
with the method of Straub (9).

Tyrosinase: Pure tyrosinase donated from Worthington Biochemical Corporation by courtesy of Dr. David W. Wylie was used.

Monoamins axidase: There were reports that the parified monoamine oxidase in serum or cytoplasma was obtaincd. 'This soluble monoamine oxidase was very wcak in its activity, while the monoamine oxidase in intracellular particle possessed strong activity. But the particle monoamine oxidase was even described as "insoluble monoamine oxidase" and a soluble preparation of the particle monoamine oxidase was very difficult to obtain. However the author succeeded in solubilizing mitochondrial particle monoamine oxidase in rat liver. The mitochondrial particles obtained from rat liver by the homogenizing with cold $0.25 \mathrm{M}$ sucrose and by centrifugation were treated with cold $0.1 \mathrm{M}$ phosphate buffer, $\mathrm{pH} 7.0$, containing $0.5 \%$ sodium cholcate and stood for several hours at $0^{\circ} \mathrm{C}$ with occasional stirring. The suspending solution was centrifuged at $10,000 \times \mathrm{g}$ for 60 minutcs. The precipitant was resuspended with $0.1 \mathrm{M}$ phosphate buffer, $\mathrm{pH} 7.0$, containing $0.5 \%$ sodium choleate and recentrifuged. To $100 \mathrm{ml}$ of combincd supernatants $14.2 \mathrm{~g}$ of ammonium sulfate was added and filtered. $13.2 \mathrm{~g}$ of ammonium sulfate was added to $100 \mathrm{ml}$ of this filtrate, and the precipitant was collected and suspended with $0.1 \mathrm{M}$ phosphate buffer at $\mathrm{pH}$ 7.0. This preparation was dialyzed against the same buffer at $\mathrm{pH} 7.0$ for 20 hours at $0^{\circ} \mathrm{C}$. This preparation from rat liver mitochondrial particles had powerful activity to oxidize monoamines.

Procedure: Goldsol was protected with the minimum but sufficient quantity of enzyme preparation, in the quantity goldsol was not coagulated cven when buffer and sodium chloride were added. When goldsol was protected with superfluous enzyme protein and then the enzyme reaction was substantiated, the color of the goldsol medium would not change, because excessive enzyme protcin would protect goldsol against cation even though protecting action of enzyme protein might decrease. When enzyme protein was insufficient, goldsol particles already had coagulated and the color of the medium would have altered by the addition of buffer and sodium chloride. Goldsol was protected with proper quantity of enzyme preparation in an extremely cleaned tube, and the buffer was added in order to get optimal pH and the substrate was added in the presence of sodium chloride. And then the goldsol medium was incubated at $37^{\circ} \mathrm{C}$. In this case substrate free mediuin was used as the control for the purpose of observing the change of the color of the medium.

\section{RESULTS}

\section{Sudies on acetylcholinesterase}

$2.2 \mathrm{ml}$ of Goldsol RV was protected with $0.1 \mathrm{ml}$ of acetylcholinesterase diluted adequately from the coagulation caused by the subsequent addition of $0.6 \mathrm{ml}$ of veronal buffer, pH 7.7 (ionic strength 0.015 ) and $0.4 \mathrm{ml}$ of $1 \%$ sodium chloridc solution. And then the goldsol medium was incubated at $37^{\circ} \mathrm{C}$ with $0.4 \mathrm{ml}$ of acetylcholine chloride 
solution as substrate. The medium with $0.4 \mathrm{ml}$ of water instead of above acetylcholine chloride solution was used as control in order to observe the change of the color of the medium (Table 1A).

After the incubation at $37^{\circ} \mathrm{C}$ for $7-8$ minutes without preincubation the color of the goldsol medium with acetylcholine altered rapidly from pink to purple blue and then gradually faded. After incubation for 10 minutes the changes of the color of the medium were shown in Table 1B. In proportion to the concentration of acctylcholine as substrate, the color of the medium altercd.

TABI, 1. Application of goldsolreaction for acctylcholinesterase.

A) Assay procedure :

Into glass tube are placed the following :

\begin{tabular}{|c|c|c|c|c|}
\hline & & \multicolumn{2}{|c|}{ Test } & Control \\
\hline \multicolumn{2}{|l|}{ Goldsol (RV) } & \multicolumn{2}{|c|}{$2.2 \mathrm{ml}$} & $2.2 \mathrm{ml}$ \\
\hline \multicolumn{2}{|l|}{ ACh-ase } & \multicolumn{2}{|c|}{$0.1 \mathrm{ml}$} & $0.1 \mathrm{mI}$ \\
\hline \multicolumn{2}{|c|}{ Veronal buffer, $\mathrm{pH} 7.7$} & \multicolumn{2}{|c|}{$0.6 \mathrm{ml}$} & $0.6 \mathrm{ml}$ \\
\hline $1 \% \mathrm{NaCl}$ & & \multicolumn{2}{|c|}{$0.4 \mathrm{ml}$} & $0.4 \mathrm{ml}$ \\
\hline Substrate & & \multicolumn{2}{|c|}{$0.4 \mathrm{ml}$} & - \\
\hline $\mathrm{H}_{3} \mathrm{O}$ & & \multicolumn{2}{|l|}{-} & $0.4 \mathrm{ml}$ \\
\hline Addition & Final conc. & ACh-ase & Incub. temp. & Change of color \\
\hline $\mathrm{ACh}$ & $10 \mathrm{~mm}$ & native & $37 \mathrm{C}$ & $H$ \\
\hline $\mathrm{ACh}$ & $20 \mathrm{~mm}$ & nativc & $37^{\circ} \mathrm{C}$ & $H H$ \\
\hline $\mathrm{ACh}_{\mathrm{H}}$ & $10 \mathrm{mM}$ & native & $0^{\circ} \mathrm{C}$ & - \\
\hline $\mathrm{ACh}$ & $10 \mathrm{mM}$ & inactive* & $37^{\circ} \mathrm{C}$ & - \\
\hline Benzoylcholine & $10 \mathrm{~mm}$ & native & $37^{\circ} \mathrm{C}$ & -- \\
\hline Carbamylcholine & $10 \mathrm{~mm}$ & native & $37^{\circ} \mathrm{C}$ & - \\
\hline
\end{tabular}

*The enzyme was inactivated by incubating at $50^{\circ} \mathrm{C}$ for $30 \mathrm{~min}$.

When the medium was kept at $0^{\circ} \mathrm{C}$ or when goldsol was protected with inactivated acetylcholinesterase by incubation at $50^{\circ} \mathrm{C}$ for 30 minutes, the color of the medium did not alter in spite of the addition of acetylcholine chloride solution. If goldsol was protected with minimum protectable quantity of egg albumin against buffer and sodium chloride, we could not obscrve the change of the color of the medium with acetylcholine. That is; changes of color of the goldsol medium seemed to be parallel to the activitics of acetylcholinesterase. $\Lambda$ s this enzyme is specific cholinestcrasc, the color of the medium did not alter when benzoylcholine or carbamylcholine was added at the same concentration as that of acetylcholine solution. Fig. 1 showed that the change of the color of goldsol medium preceded the occurrence of the enzymatic hydrolysis of acetylcholine. When choline and acetate at the same time were added to the substrate free medium at the same concentration as the one formed from acetylcholine by 10 minute incubation in the complete system, the color of the medium did not alter. 

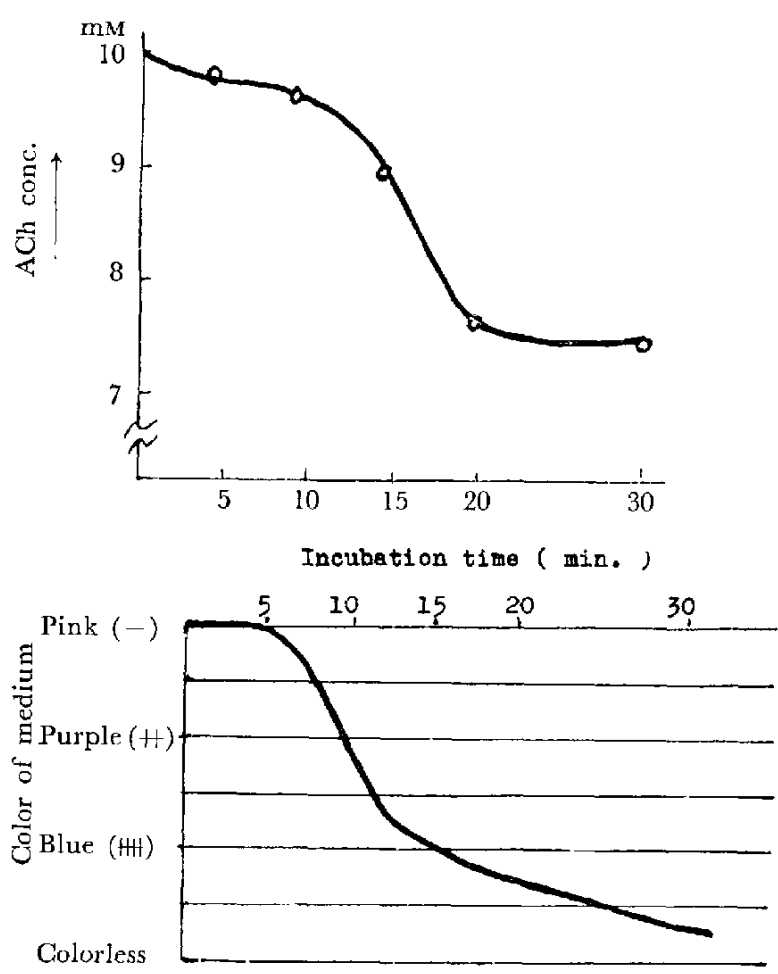

FIG. 1. Time coursc of ACh concentration.

Table 2 shows the effects of cholinesterase inhibitors on the goldsolreaction. The addition of eserine did not bring the change of the color of the medium at the final concentration of $10^{-4} \mathrm{M}$ or $10^{-3} \mathrm{M}$ against the control. It was of interest that the pretreatment of eserine negated the effect of acetylcholine addition on the goldsolreaction. However, although $10^{-4} \mathrm{M}$ of thiamine did not cause the change of the color of the medium, $10^{-9} \mathrm{M}$ of thiamine brought the change of that. In this casc thiamine inhibited the cholinesterase at the concentration of $10^{-3} \mathrm{M}$, but the $10^{-4} \mathrm{M}$ of thiamine could not inhibit the cholinesterase $(10,11)$. The color of the goldsol medium protected with inactivated acetylcholin-

TABLE 2. Fffects of ACh-ase inhibitor on goldsolreaction.

\begin{tabular}{|c|c|c|c|c|}
\hline \multirow{3}{*}{$\begin{array}{c}\text { Addition } \\
\text { (Final conc.) } \\
\text { Eserine sulfate } \\
\left(10^{-4} \mathrm{M}\right)\end{array}$} & \multirow[t]{2}{*}{ Gontrol } & \multirow[t]{2}{*}{ ACh-ase } & \multicolumn{2}{|c|}{$\begin{array}{l}\text { Change of color } \\
\text { Incubation time }\end{array}$} \\
\hline & & & $10 \mathrm{~min}$ & $20 \mathrm{~min}$ \\
\hline & $\begin{array}{l}\mathrm{H}_{2} \mathrm{SO}_{4} \\
\left(10^{-4} / 2 \mathrm{M}\right)\end{array}$ & native & - & - \\
\hline $\begin{array}{l}\text { Eserine sulfate } \\
\qquad\left(10^{-2} \mathrm{M}\right)\end{array}$ & $\begin{array}{l}\mathrm{H}_{42} \mathrm{SO}_{4} \\
\left(10^{-3} / 2 \mathrm{M}\right)\end{array}$ & native & - & $\cdot-$ \\
\hline $\begin{array}{rr}\text { Eserine sulf. }+\mathrm{ACh} \\
\left(10^{-1} \mathrm{M}\right) & (10 \mathrm{mM})\end{array}$ & $\begin{array}{l}\mathrm{H}_{2} \mathrm{SO}_{4} \\
\left(10^{-4} / 2 \mathrm{M}\right)\end{array}$ & native & - & - \\
\hline ACh $(10 \mathrm{~mm})$ & $\mathrm{H}_{2} \mathrm{O}$ & native & $H$ & $H+H$ \\
\hline$\underset{\left(10^{-4} \mathrm{M}\right)}{\text { Vitamin }} \mathrm{B}_{1} \mathrm{HCl}$ & $\begin{array}{l}\mathrm{HCl} \\
\left(10^{-1} \mathrm{M}\right)\end{array}$ & native & - & - \\
\hline$\underset{\left(10^{-9} \mathrm{M}\right)}{\text { Vitamin }} \mathrm{B}_{1}$ HCl & $\begin{array}{l}\mathrm{HCl} \\
\left(10^{-\mathrm{a}} \mathrm{M}\right)\end{array}$ & native & + & +1 \\
\hline$\underset{\substack{\text { Vitaminin } \\
\left(10^{-3} \mathrm{M}\right)}}{\mathrm{B}_{1} \mathrm{HCl}}$ & $\begin{array}{l}\mathrm{HCl} \\
\left(10^{-3} \mathrm{M}\right)\end{array}$ & inactive* & - & $-\cdot$ \\
\hline
\end{tabular}

*The enzyme was inactivated by incubating at $50^{\circ} \mathrm{C}$ for $30 \mathrm{~min}$.

esterase was not affected by the addition of $10^{-8} \mathrm{M}$ thiamine.

II. Studies on lactic dehydrogonase

Goldsol was protected with purified lactic dehydrogenase which was diluted properly, 
and in the presence of buffer and sodium chloride the medium was incubated at $37^{\circ} \mathrm{C}$ with NAD and lactate (Table 3A). The medium with additional sodium chloride in the corresponding concentration to sodium lactate was used as the control. As shown in Table 3B, the addition of lactate without coenzyme did not affect the color of the

TARLL 3. Application of goldsolreaction for lactic dehydrogenase.

A) Assay procedure :

Into glass tube are placed the following:

\begin{tabular}{lcc}
\hline & Test & Ciontrol \\
\hline Goldsol (RV) & $2.1 \mathrm{ml}$ & $2.1 \mathrm{ml}$ \\
Lactic dehydrogenasc & $0.1 \mathrm{ml}$ & $0.1 \mathrm{ml}$ \\
$0.5 \mathrm{M}$ Tris-buffer, $\mathrm{pH} 8.6$ & $0.6 \mathrm{ml}$ & $0.6 \mathrm{ml}$ \\
$5 \% \% \mathrm{NaCl}$ & $0.4 \mathrm{ml}$ & $0.4 \mathrm{ml}$ \\
$\mathrm{H}_{2} \mathrm{O}$ & - & $0.4 \mathrm{ml}$ \\
$1.5 \times 10^{-3} \mathrm{M} \mathrm{NAD}$ & $0.4 \mathrm{ml}$ & - \\
$1.1 \mathrm{M} \mathrm{NaCl}$ & - & $0.4 \mathrm{ml}$ \\
$1 . \mathrm{M} \mathrm{Na-lactate}$ & $0.4 \mathrm{ml}$ & - \\
\hline
\end{tabular}

B)

\begin{tabular}{|c|c|c|c|c|}
\hline Addition & Final conc. & LDH & Incub. temp. & Change of color \\
\hline Lactate & $0.11 \mathrm{M}$ & native & $37^{\circ} \mathrm{C}$ & - \\
\hline NAD & $1.5 \times 10^{-4} \mathrm{M}$ & native & $37^{\circ} \mathrm{C}$ & $+i$ \\
\hline $\begin{array}{l}\mathrm{NAD} \perp \\
\text { Lactate }\end{array}$ & $\begin{array}{l}1.5 \times 10^{-4} \mathrm{M} \\
0.11 \mathrm{M}\end{array}$ & native & $37^{\circ} \mathrm{C}$ & HH \\
\hline $\mathrm{NAD+}_{\text {Lactate }}$ & $\begin{array}{l}1.5 \times 10^{-4} \mathrm{M} \\
0.11 \mathrm{M}\end{array}$ & inactive* & $37 \mathrm{C}$ & - \\
\hline$\underset{\text { Lactate }}{\mathrm{NAD}+}$ & $\begin{array}{l}1.5 \times 10^{-4} \mathrm{M} \\
0.11 \mathrm{M}\end{array}$ & native & $0^{\circ} \mathrm{C}$ & - \\
\hline
\end{tabular}

* The enzyme was inactivated by incubating at $60^{\circ} \mathrm{C}$ for $30 \mathrm{~min}$.

medium, but the addition of NAD without substrate brought the change of the color of the medium and the addition of both NAD and lactate altered the color more remarkably than NAD alone. At $0^{\circ} \mathrm{C}$ the color of the medium did not alter in the presence of $\mathrm{NAD}$ and lactate and in the case of inactivated lactic dehydrogenase which had heated at $60^{\circ} \mathrm{C}$ for 30 minutes the color did not also alter during incubation at $37^{\circ} \mathrm{C}$.

\section{Studies on tyrosinase}

Goldsol was protected with tyrosinase diluted properly, in the presence of buffer and sodium chloride, after the addition of substrate, the mixture was incubatcd at $37^{\circ} \mathrm{C}$ under anaerobic condition (Table 4). After several minutes the color of the medium altered rapidly. The color of the medium with adrenaline as substrate altered earlier than with tyrosine. However after incubation for 15 minutes the color of the medium with tyrosine as substratc altered more prominently than that with adrenaline (Fig. 2). After the change of the color of the medium the supply of oxygen formed the quinone 
TABLE 4. Application of goldsolrcaction for tyrosinase.

Procedure : Into Thunberg's tube are placed the following :

\begin{tabular}{|c|c|c|c|}
\hline & & Test & Gontrol \\
\hline \multirow{3}{*}{ Main chamber } & Goldsol (RV) & $2,1 \mathrm{ml}$ & $2.1 \mathrm{ml}$ \\
\hline & Tyrosinase in $\mathrm{H}_{2} \mathrm{O}$ & $0.1 \mathrm{ml}$ & $0.1 \mathrm{ml}$ \\
\hline & $0.2 \mathrm{M}$ phosphate buffer, $\mathrm{pH} 6.5$ & $0.5 \mathrm{ml}$ & $0.5 \mathrm{ml}$ \\
\hline \multirow{2}{*}{ Side arm } & Substrate in $0.1 \mathrm{~N}-\mathrm{HCl}$ & $0.3 \mathrm{ml}$ & - \\
\hline & $0.1 \mathrm{~N}-\mathrm{HCll}$ & - & $0.3 \mathrm{ml}$ \\
\hline
\end{tabular}

Substrate was added under anaerobic condition.

Incubation time

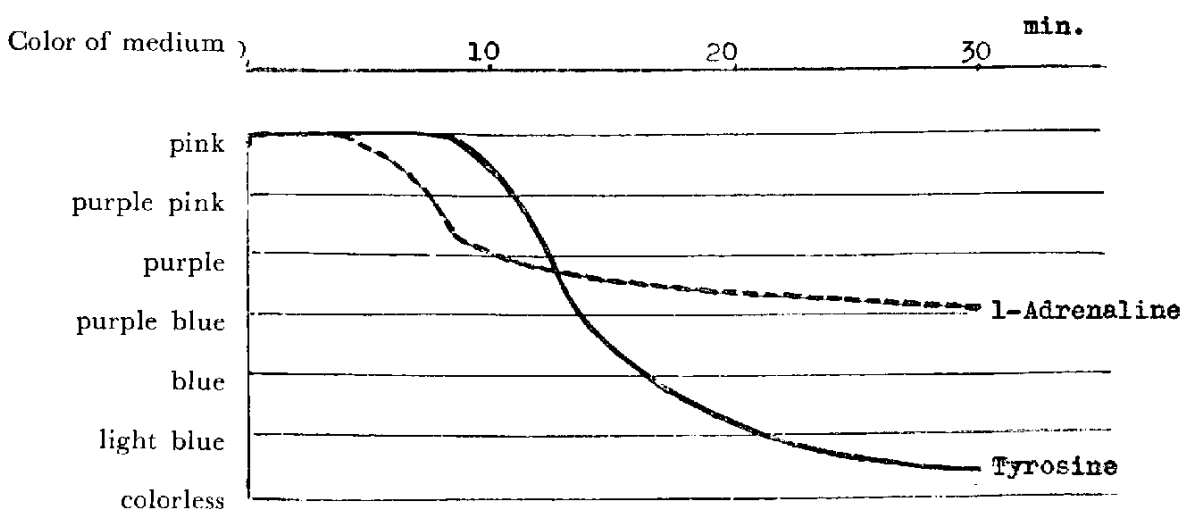

FiG. 2. Effects of substrate on the goldsol protected with tyrosinase. Incubation at $37^{\circ} \mathrm{C}$ without preincubation.

bodies. Inactivated tyrosinase which had incubated at $50^{\circ} \mathrm{C}$ for 30 minutes could not protect goldsol against sodium chloride. This point differs from the case of cholinesterase or lactic dehydrogenase.

\section{$I V$. Studies on monoamine oxidase}

Michaelis constants of tyramine, hydroxytyramine, noradrenaline for the soluble monoamine oxidase preparation from mitochondrial particles of rat liver werc shown in Table 5B. Goldsol was protected by this monoamine oxidase preparation diluted properly against buffer and sodium chloride, as shown in Table 5A, and then under

TABLE 5. Application of goldsolreaction for monoamine oxidase.

A) Procedure: Into Thunberg's tube are placed the following :

\begin{tabular}{|c|c|c|c|}
\hline & & Test & Control \\
\hline \multirow{4}{*}{ Main chamber } & Goldsol (RV) & $2.1 \mathrm{ml}$ & $2.1 \mathrm{ml}$ \\
\hline & Monoamine oxidase & $0.1 \mathrm{ml}$ & $0.1 \mathrm{ml}$ \\
\hline & $0.2 \mathrm{M}$ phosphate buffer, $\mathrm{pH} 7.4$ & $1.0 \mathrm{ml}$ & $1.0 \mathrm{ml}$ \\
\hline & $50 \% \mathrm{NaCl}$ & $0.4 \mathrm{ml}$ & $0.4 \mathrm{ml}$ \\
\hline \multirow{2}{*}{ Side arm } & $0.2 \mathrm{M}$ Substrate & $0.4 \mathrm{ml}$ & - \\
\hline & $0.2 \mathrm{M} \mathrm{HCI}$ & - & $0.4 \mathrm{ml}$ \\
\hline
\end{tabular}

Substrate was added under anaerobic condition. 
B) Comparison of goldsolreaction with Michaelis constant.

\begin{tabular}{lrc}
\hline & Michaelis const. & $\begin{array}{c}\text { Goldsolrcaction } \\
\text { (Change of color) }\end{array}$ \\
\cline { 3 - 3 } 3-Hydroxytyramine & $0.6 \times 10^{-8} \mathrm{M}$ & + \\
Tyramine & $1.4 \times 10^{-8} \mathrm{M}$ & + \\
l-Noradrenaline & $7.2 \times 10^{-3} \mathrm{M}$ & \pm \\
l-Adrenaline & $10.7 \times 10^{-3} \mathrm{M}$ & $=$ \\
\hline
\end{tabular}

anaerobic condition the medium was incubated with substrate at $37^{\circ} \mathrm{C}$. Table $5 \mathrm{~B}$ shows the relation of Michaclis constants and the results of the goldsolreaction after 10 minute incubation. In this case the color of the medium altered in an inverse proportion to Michaelis constant.

\section{DISCLSSION}

When goldsol particles charged in negative were protected with minimum protectable quantity of the soluble enzyme preparation against buffer and sodium chloride and the mixture was incubated with substrate, the protecting action of cnzyme protein was weakend and goldsol particles were attacked by cation, neutralized, and coagulated; that is, the color of the goldsol medium altered obviously by the coagulation of the particles. This goldsolreaction did not occur when the incubation temperature was $0^{\circ} \mathrm{C}$ or cnzyme was inactive (Tablc I, 3). Certainly this goldsolreaction may be enzymic reaction. When goldsol was protected with acetylcholinesterase, the goldsolreaction showed the substrate specificity (Table 2) and as shown in Fig. 1, the color of the goldsol medium altered before the formation of the endproducts. When the endproducts formed after the goldsol coagulation were added to the goldsol medium protected under same conditions and then the medium was incubated, the color of the goldsol medium did not alter. Above data suggest that this change of the color of the goldsol medium may depend upon the occurrence of the change of the ccnfiguration of enzyme protein by the formation process of enzyme-substrate complex (Fig. 3). This conception was supported by the fact that Michaelis constants of the monoamine oxidase were reciprocal

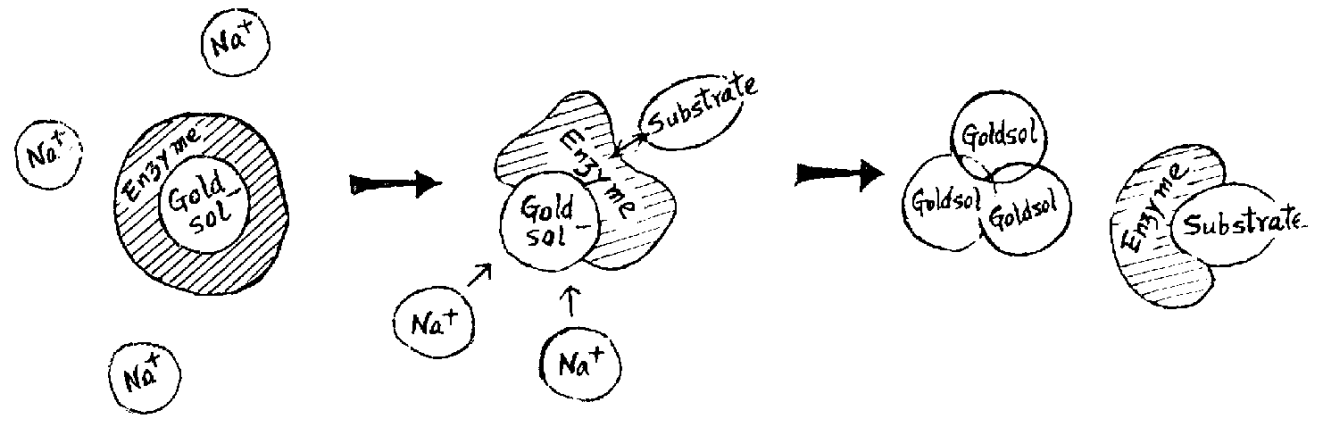

FIG ${ }_{r}$ 3. Enzymc-substrate complex on goldsolreaction, 
to the changc of the color of the goldsol medium. Therefore, we could know the cnzyme-substrate affinity by obscrving the change of the color through the goldsol medium. That is, the more strong enzyme-substratc affinity is, the more remarkable alteration of the color of the gcldsol medium should be obtained. The data of cholinesterase (Table 2) suggest that the inhibition mechanism of cscrine to cholinesterase may differ from that of thiamine. Eserine would inhibit the formation of cholinesterase-acetylcholine combination but did not affect the protecing action of the enzyme protein for goldsol particles. The fact that $10^{-3} \mathrm{M}$ of thiamine changes the color of the goldsol medium protected with acetylcholinestcrase might be derived from the change of the configuration of cholinesterase. 'Thus it may be possible that goldsolreaction can be used for the investigation of the mechanism of the enzyme inhibition in future.

Consideration of the occurrence of the charge-transfer complex advocated by Mulliken (12) may illustrate the data of latic dehydrogenase (Table 3). Kosower (13) applied this consideration to N $\Lambda$ D-enzyme and they abserved the complex formed with NAD as the alteration of the spectra absorptions. Here we might be able to know the change of the configuration of lactic dehydrogenase by the addition of NAD through such a simple goldsolreaction. NAD is combined to latic dehydrozenase on the site which differs from that where substrate combines to. And when a specific complex is formed, "substrate site" on the emzyme becomes active. The formation procedure of this complex might decrease the protecting action of the enzyme protein for goldsol and may change the color of the goldsol medium. Without NAD, this complex does not occur and lactate can not be combined to enzyme, namely complete complex is not formed. Therefore the addition of lactate alone did not bring the change of the color of the goldsol medium. When the substrate site on the enzyme becomes active by the addition of NAD, the addition of lactate may decrease the protecing action of enzyme protein for goldsol remarkably.

The data of Fig. 2 and Table 5 suggest that under anaerobic conditions enzymesubstrate complcx may be formed. The difference of the beginning and the degree of the goldsolreactions between tyrosine and adrenaline as substrate for tyrosinase (Fig. 2) might be bascd on the difference of the affinity of enzyme to substrate. Dclay of the beginning the goldsolreaction with tyrosine as substrate may agree with the induction period. During this period the change of the configuration of tyrosinase such as weakening the protecting action for goldsol might not occur. When tyrosine was added as substrate, the color of the goldsol medium altered more prominently than in the case of adrenaline as substrate. That may depend on the more noted change of the configuration of enzyme protein caused by the duplicate activity. Though the native tyrosinase protected goldsol, the inactivated tyrosinase could not protect goldsol. This fact suggests that tyrosinase is inactivated by the degeneration of enzyme protein.

On the other hand the enzymes such as urease and alcohol dchydrogenase could not be applied for the goldsolreaction, because the native urease had not the protecting action for goldsol and the addition of alcohol as substrate may make some change of 
the nature of the suspensoid though alcohol dehydrogenase possessed the colloid protecting action.

In conclusion this paper reported a new application of goldsolreaction to enzymological studies. Further studies are required to make good use of the application of this goldsolreaction by colloidchemists and enzymologists.

\section{SUMMARY}

1. When goldsol (RV) was protected with a minimum protectable quantity of enzyme preparation against buffer and sodium chloride and the enzyme rcaction was started by the addition of the substrate, the cclor of the goldsol medium altered remarkably. The addition of the substrate weakend the protecting action of enzyme protein for goldsol and then the color of the medium altered by the coagulation of goldsol particles. From the experimental data using acetylcholinesterase, lactic dehydrogenase, tyrosinase and monoamine oxidase, it was assumed that the change of the color of the medium might be caused by the change of the configuration of enzyme protein in the process of the formation of enzyme-substrate complex.

2. The changes in color of the goldsol medium were reciprocal to Michaelis constants on the experiments using monoamine oxidase.

3. The reaction curve of goldsol medium protected with tyrosinase indicated the duplicate activity when the substrate was tyrosine, and coincided with induction period when the substrate was adrenaline.

4. Presuming from the fact that inactivated tyrosinase did not possess the protecting action for goldsol, the inactivation of tyrosinase might be depend on the degeneration of enzyme protein.

5. From the data of the goldsolreaction the difference of the mechanism of cholinesterase inhibition between escrine and thiamine was clarified.

6. Mitochondrial monoamine oxidase from rat liver was succeeded in solubilization.

Acknowledgement: I wish to express my grateful appreciation to Prof. R. Imaizumi and Dr. N. Nishino for thcir valuable suggestions.

\section{RFFERENCES}

1) ZsIGMONDY, R. : Kolloidchemie von R. Zsigmondy (1902)

2) LANGF, C. : Z. Chemotherap. 1, 44 (1912)

3) LA.vge, C. : Amer. J. Syph. Gonor. Ven. Dis. 23, 638 (1939)

4) Lange, C., Millek, J.K. and Harris, A.H. :J. clin. Path. 20, 872 (1950)

5) Mhalagan, N.F. : Brit. J. exp. Path. 27, $369\langle 1946\rangle$

6) Nishino, N. : Osaka Igaku Zassi 38, 301 (1939) (Japanese)

7) Mounter, L.A. and WhiГTAKlik, V.P. : Biochem. J. 47, 525 (1950)

8) Mounter, L.A. and WittTaker, V.P. : Ibil. 54, 551 (1953)

9) Straub, F.B. : Ibid. 34, 438 (1940)

10) Glick, D. ANd Antropeld, W. :J. Pharmacol. 65, 389 (1939)

11) ZeL.er, E. A. : Helv. chim. acta 22, 837 (1939)

12) Mulliken, R.S. :J. phys. Chem. 56, 801 (1952)

13) Kosower, E.M. : J. Amer. Chem. Soc. 78, 3497 (1956; 